\title{
Teaching learning materials in the early childhood care and education centre in Golaghat district of Assam
}

\section{SAMPREETY GOGOI}

Received: 06.11.2015; Accepted: 29.11 .2015

Author for Correspondence :

SAMPREETY GOGOI

Sarba Siksha Abhiyan Mission

Golaghat, GOLAGHAT (ASSAM) INDIA

Email: sampreetygogoi@gmail.com

\begin{abstract}
The Early Childhood Care and Education favour on the holistic development of the child and prepares child for school. It is expected to provide necessary maturational and experimental readiness to the child for meeting the demands of primary school curriculum. Early childhood development is therefore globally acknowledged as a significant input for lifelong development and successful completion of primary education. The objective of the study is toassess the availability of the teaching learning materials in the early childhood care and education center and to assess the acceptability of teaching learning materials by young children. The schools were from both the urban areas and the rural areas of Golaghat district of Assam. For selection of the samples 20 numbers of schools from each of the five educational blocks were selected. A checklist has been prepared for the teachers of the early childhood care and education centers. For analysis of surveyed data the interview schedule was thoroughly coded and appropriates tables were designed. Preliminary analytical devices expressed in frequency and percentages were used. The observation method was mainly used in the study to see the acceptability of teaching learning materials by young children. 98 per cent of the schools were having the teaching learning materials for the early childhood care and education. 60 per cents replied that the teaching learning materials were locally prepared, 92 per cent of the teachers also replied that the teaching learning materials was supplied from the Government of Assam. The children are more involved with activities when the teaching learning materials are administered to them. It has been observed that the children acceptance is more and learning is more effective with the use of teaching learning materials and the environment created is more joyful and child centric.
\end{abstract}

KEY WORDS: Teaching learning materials, Early Childhood Care and Education Center

- HOW TO CITE THIS PAPER : Gogoi, Sampreety (2015). Teaching learning materials in the early childhood care and education centre in Golaghat district of Assam. Asian J. Home Sci., 10 (2) : 471-475. 